Pesq. Vet. Bras. 37(1):36-40, janeiro 2017

DOI: $10.1590 / \mathrm{S} 0100-736 \mathrm{X} 2017000100006$

Topic of General Interest

\title{
C-Peptides for diagnostics and therapy: a veterinary medicine point of view ${ }^{1}$
}

\author{
Derek A. Rosenfield ${ }^{2 *}$, Marcilio Nichi ${ }^{2}$ and Cristiane Schilbach Pizzutto ${ }^{2}$
}

\begin{abstract}
Rosenfield D.A., Marcilio Nichi \& Pizzutto C.S. 2017. C-Peptides for diagnostics and therapy: a veterinary medicine point of view. Pesquisa Veterinária Brasileira 37(1):36-40. Departamento de Reprodução Animal, Faculdade de Medicina Veterinária e Zootecnia, Universidade de São Paulo, Av. Prof. Dr. Orlando Marques de Paiva 87, Cidade Universitária, São Paulo, SP 05508-270, Brazil. E-mail: dro@usp.br

Empirical studies proved that C-peptides are performing numerous intrinsic biological roles, and serve as a marker for pancreatic performance analysis. Since the last decade, C-peptide assays for differential diagnosis in veterinary diabetic patients are becoming more available, but still only for a very limited number of species. Studies on C-peptide as a diagnostic tool, therapy for associated complications, or as replacement therapies for C-peptide deficiency still showed not to be a common practice in veterinary medicine. This review was conducted to determine the potential importance of C-peptide in Veterinary Medicine, relevant in the diagnosis of diabetes and for other metabolic processes, as well as its proposed therapeutic benefits. Numerous articles were identified that reported positive results in their experimental studies, whether C-peptide as a biomarker for pancreatic performance in dogs, cats, and horses, as a non-invasive method to monitor nutritional status in primates, or to investigate its potential therapeutic benefits for diabetes-related illnesses.
\end{abstract}

INDEX TERMS: C-peptide, diabetes mellitus, non-invasive monitoring, therapy, veterinary medicine.

RESUMO.- [Peptídeos-C para diagnóstico e terapia: um ponto de vista na medicina veterinária.] Os estudos empíricos provaram que o peptídeo $\mathrm{C}$ realiza várias funções biológicas intrínsecas e serve também como um marcador para a análise de desempenho do pâncreas. Nesta última década os ensaios peptídeo $\mathrm{C}$ para o diagnóstico diferencial em doentes diabéticos veterinários estão mais disponíveis, contudo apenas em um limitado número de espécies. Estudos sobre C-peptídeo como ferramenta de diagnóstico, terapia de complicações associadas ou como terapias de reposição na sua deficiência ainda não é prática comum na Medicina Veterinária. Esta avaliação foi realizada para determinar a importância potencial de peptídeo $\mathrm{C}$ na $\mathrm{Me}$ dicina Veterinária, relevante no diagnóstico de diabetes e também em outros processos metabólicos, assim como os benefícios terapêuticos propostos. Foram identificados nu-

\footnotetext{
${ }^{1}$ Received on April 13, 2016.

Accepted for publication on July 28, 2016.

${ }^{2}$ Programa de Pós-Graduação em Reprodução/Silvestres, Departamento de Reprodução Animal, Faculdade de Medicina Veterinária, Universidade de São Paulo (USP), Av. Prof. Dr. Orlando Marques de Paiva 87, Cidade Universitária, São Paulo, SP 05508-270, Brazil. *Corresponding author: dro@usp.br
}

merosos artigos que reportaram resultados positivos nos seus estudos experimentais, quer o peptídeo $\mathrm{C}$ fosse utilizado como biomarcador para o desempenho do pâncreas em cães, gatos e cavalos, como um método não invasivo para monitorar o estado nutricional em primatas, quer para investigar o seu potencial terapêutico benéfico para doenças relacionadas ao diabetes.

TERMOS DE INDEXAÇÃO: Peptídeo C, Diabetes mellitus, monitorizarão não invasiva, terapia, veterinária.

\section{INTRODUCTION}

Diabetes in animals? It seems awkward for the general public to apply the concept of human illnesses to the animal world; but indeed the impact of human activities and lifestyle, as inflicted upon domestic animals and wildlife, bears its consequences. How is that possible, one might ask, and the answer can be as simple as looking at the obvious causes for human diabetes, or it can be as complex as studying the disease's multifactorial origin, together with the typical and immense veterinary challenge, the large variety of species and their particularities. In the classical etiological aspect, Type I diabetes mellitus (DM) might be 
the result of a genetic disposition (Støy 2014), or the immunological destruction of the pancreatic $\beta$-cells, leading to a progressive, or eventually, complete loss of insulin production. Type $2 \mathrm{DM}$ adds a peripheral insulin resistance to the non-functional islets of Langerhans, where in addition to metabolic abnormalities and ambient factors, other contributing diseases play an important role, for example, pancreatitis, acromegaly in cats, or hyperadrenocorticism in dogs. Additionally, pancreatic complication might arise from iatrogenic provocations, plus the common cause of an inactive lifestyle, leading to various degrees of obesity. Type I DM is a more common in dogs, whereas Type 2 DM a rather rare occurrence, but on the other hand, it is quite common in felines (Ettinger \& Feldman 2005, Bachem 2015).

In fact, diabetes mellitus is one of the most common endocrinological diseases in dogs and cats (Ettinger \& Feldman 2005, Kumar et al. 2014), and case numbers are steadily increasing. As before mentioned, it is a multifactorial disease, with genetic predisposition, ingestion of highly treated and caloric animal feeds, drug treatments, daily inactivity, weight gain, or a combination of all the above, contributing to additional systemic pathologies, circulatory problems, and muscle weakness, among others.

The common challenge in the differential diagnosis of Diabetes mellitus, (insulin resistance vs. pancreatic deficiency), lays within the broad range of species, breed, age, and individual particularities, which all needs to be considered. Also, the unfortunate possibility, that these animals are not seen by a veterinarian until the clinical signs, such as polydipsia, polyuria, polyphagia, and weight loss, are quite evident to the owner. Meaning, by that moment the illness progressed already into severe stages, with hyperglycemia and glycosuria quite evident, regardless of the type of DM.

In veterinary medicine, diabetes is classified into IDDM and NIDDM based on their course of treatment, rather than called type I or type II diabetes, as it is considered clinically more accurate and relevant (Ettinger \& Feldman 2005). Nonetheless, certain difficulties, as before mentioned, lies within the differential diagnosis between Insulin-dependent diabetes mellitus (IDDM) and Non-insulin-dependent diabetes mellitus (NIDDM). Depending on the species, some might not respond to classical diagnostic tools, such as glucose or glucagon challenges, or some might even alternate between insulin-dependent and insulin non-dependent conditions, subject to the disease progress, particularly felines. Consequently, differentiation is often made retrospectively, by assessing the animal's response to therapy. Needless to say, any better means to diagnose quickly and accurately, not losing time over identifying the right course of treatment, increasing the chance to combat this disease successfully.

In recent years, a number of studies have shown great success in employing C-peptide as a diagnostic tool (Besch et al. 1985, Montgomery et al. 1996, Tóth et al. 2010, Greco 2016). Not just for the diabetes disease, but as a novel means of non-invasive monitoring of nutritional feed intake, as well as its use in certain therapeutical applications.
The objective of this review is to show the status quo of C-Peptide in its potential use in veterinary medicine for diagnostic and treatment.

\section{MATERIALS AND METHODS}

Literature review. We used a keyword search in scientifically oriented databases and search engines, such as SciELO, SCOPUS, Science Direct, Google Scholar, BioOne, PubMed, and MEDLINE, among others. Scanning Titles, Abstracts, and Keywords, to identify relevant articles (experimental research, and literature reviews) on C-peptide applications, with emphasis on Veterinary Medicine.

Once articles were identified, a full-text review was conducted and selected for inclusion, or rejection. We considered as relevant, peer-reviewed, experimental studies and comprehensive reviews, published in indexed journals, with human or mammalian subjects. Non-English publications, case reports, organ transplant studies, and in-vitro studies were excluded.

C-peptide, also referred to as a connecting peptide, and depending on the species, has a combination of up to 31 amino acids, representing the C-terminal cleavage product, fashioned during the process from an insulin prohormone into an active insulin molecule. The proinsulin suffers a cleavage (split) when secreted, in equimolar quantities, from the pancreas into the bloodstream, see Figures 1 and 2. Although the C-Peptide discovery happened 1967 , for the longest time, it was believed to be inert of any bioactivity. However, about 20 years ago, it became more and more evident that $\mathrm{C}$-peptide does not just serve for the structural integrity of Insulin, but also plays a significant biologically active role (Wahren et al. 2007, Sanlioglu et al. 2013, Bachem 2015, Støy 2014).

Pathophysiology of Diabetes mellitus in Veterinary Medicine. Diabetes mellitus should not be confused with Diabetes insipidus, an unrelated hormonal disorder, although, might show signs and symptoms that are similar to DM, for example, polydipsia and polyuria.

As before mentioned, diabetes mellitus can be classified as insulin-dependent DM or noninsulin-dependent DM. In feline species, we further differentiate between "Transient Diabetes Mellitus", which simply refers to a possible reversibility of the disease after the initial treatment, "Permanent DM", or "Spontaneous DM". In animals, spontaneous DM can be comprised of all classified types of diabetes. In equine species, while a rare occurrence, the

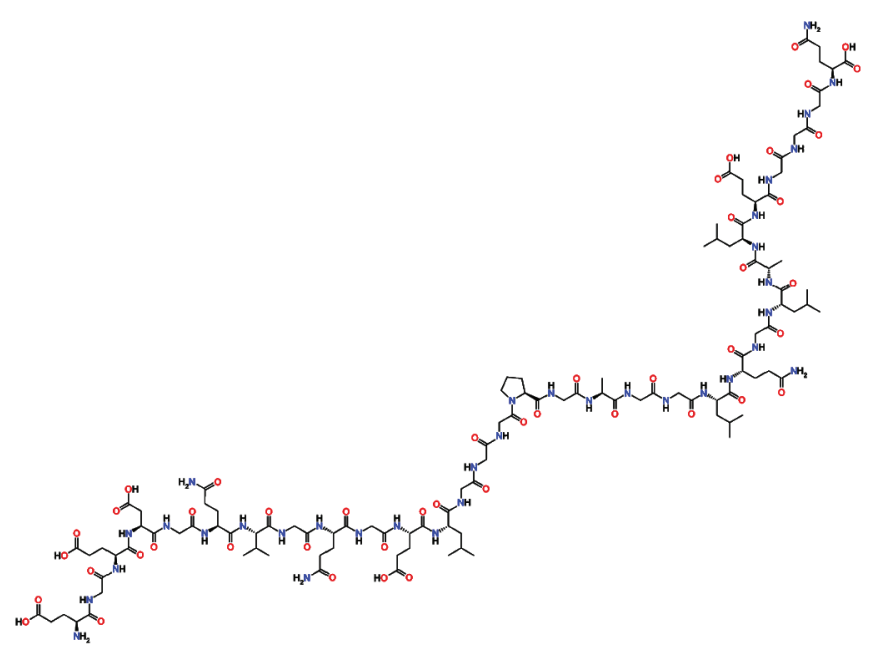

Fig.1. Source: JaGa; CC BY-SA 3.0; Skeletal diagram of C-peptide. 2008. 


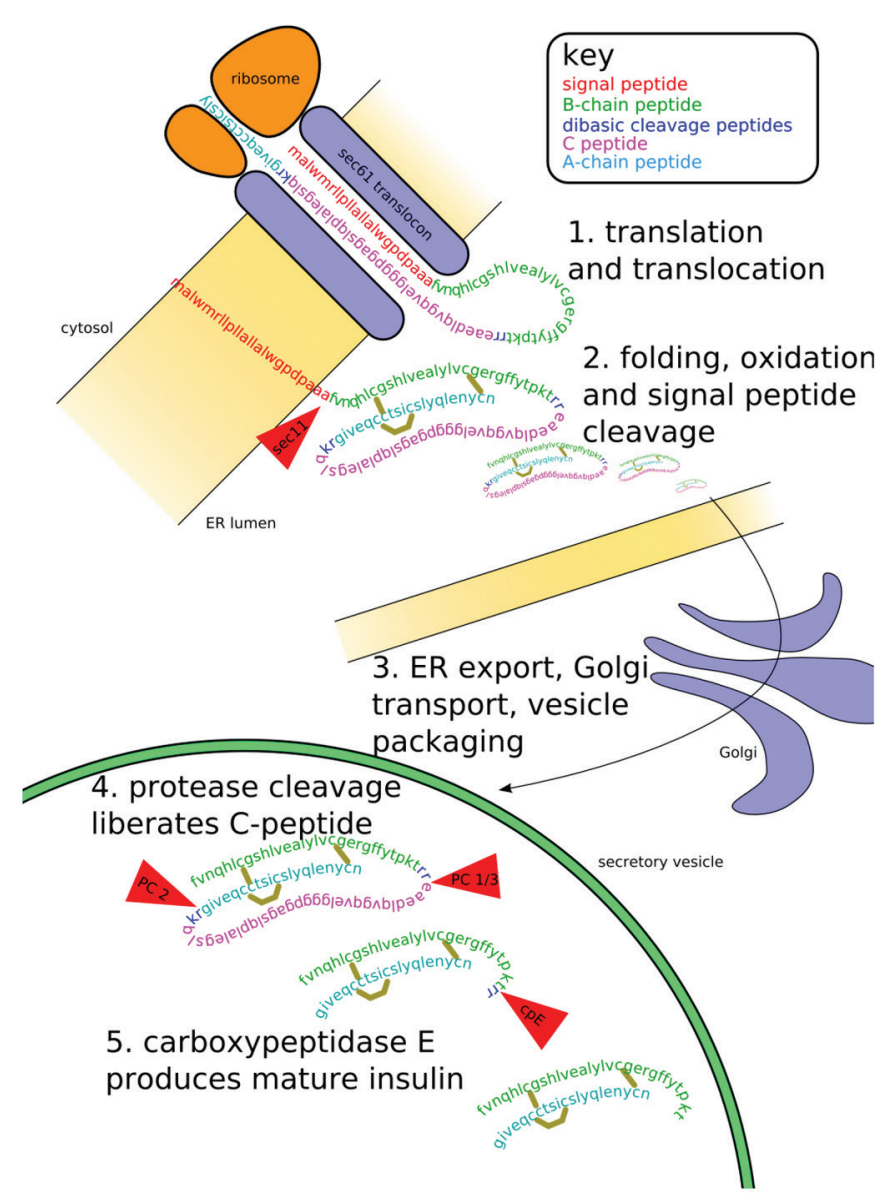

Fig.2. Insulin Pathway and C-Peptide liberation during normal Insulin production. Cell components are not to scale. Image by Isaac Yonemoto, 2006.

express types might be insulin-dependent, noninsulin-dependent, or secondary diabetes. Insulin-dependent DM is a common form in domestic ruminants and domestic canines, whereas in felines, spontaneous, noninsulin-dependent, similar to the human type II diabetes, are more prominent.

In female canines, periods of diabetic onset, due to gestational, cyclic activity during the diestrus phase, or because of a persistent corpus luteum, have been observed. Furthermore, in captive wildlife, diabetes might be provoked by stress and sudden lifestyle and dietary changes, and a severe lack of physical activity, and associated systemic illnesses (O'Brien 2002).

For DM to occur, two principal pathophysiological mechanis$\mathrm{ms}$ are involved. First, $\beta$-cells of the pancreatic islets become partially, or entirely deficient in secreting insulin. The lack of insulin presence in the circulatory system will, in turn, initiate a compensatory effect by accelerating glycogenolysis and gluconeogenesis, resulting, together with the decreased glucose, amino acids, and fatty acids cell absorption, in hyperglycemia. Once the blood-sugar concentrations reach excessive levels, the renal tubular cells will lose its capacity to reabsorb the glucose molecules from the generated ultrafiltrate, leading to glycosuria.

Other possible contributing factors are the formation of anti-insulin antibodies, damage to In this literature review, numerous articles on $\mathrm{C}$ peptide studies were identified, reporting positive results from their empirical research, validating $C$ peptide applications as an important tool in human medicine, as well as veterinary medicine, whether as a biomarker for pancreatic performance in for dogs, cats, and horses, or as a non invasive method to monitor nutritional status in primates, or to investigate its potential therapeutic benefits for diabetes related illnesses and $C$ Peptide deficiency. $\beta$-cells from immune-mediated islet cytotoxicity, or inappropriate secretion of hormones by neoplasm. Also, added provocateurs are idiopathic atrophy, or pancreatitis, which will result in the destruction of the pancreatic parenchyma by replacing the endocrine and exocrine cells with fibrous connective tissues.

In felines, the common cause for the failure of pancreatic function is due to the deposit of amyloid in the islets, responsible for the degenerative changes in $\alpha$ and $\beta$-cells alike (O'Brien 2002, Ettinger \& Feldman 2005, McGavin \& Zachary 2007). Furthermore, a chronic increase of the glucose blood concentration occurs due to peripheral insulin resistance. A pathological mechanism, whereby, insulin-stimulated glucose absorption of the skeletal muscle (same dynamics for other tissues) is distinctly decreased, because of impaired insulin cell-signaling and other intracellular defects, together with reduced glucose transportation,- phosphorylation,oxidation, and glycogen synthesis (Abdul-Ghani \& De Fronzo 2010).

Other Diabetes mellitus associated complications are retinopathy, nephropathy, neuropathy and cardiovascular diseases.

C-Peptide deficiency. In diabetes mellitus, due to the destruction of $\beta$-cells, the production and secretion of endogenous insulin will be reduced, and consequently, result in a reduced C-peptide plasma concentration. We know that C-peptide, as an integral component of insulin synthesis, is released into the bloodstream in equimolar quantities (Wahren et al. 2007, Ghorbani \& Shafiee-Nick 2015), and for the longest time believed to be inert as a biological agent. However, empirical studies have proven C-peptide's involvement in a number of biological processes, and it can, therefore, be argued, that a deficiency of C-peptide would have detrimental consequences in those biological processes.

In their latest study Ghorbani \& Shafiee-Nick (2015), confirm the clinical importance of C-peptide replacement, together with the regular insulin therapy, to prevent, retard, or ameliorate diabetic complications in diabetic patients.

C-Peptide as a diagnostic tool for pancreatic performance and diabetes. In Veterinary Medicine, the classical approach to diagnosing DM and differentiate DMs, would normally start with an anamnesis, where the first difficulty is encountered, due to the lack of the family history of the pet, and even more so in wildlife animals, which is simply unknown. Considering the clinical signs, in general, are not very indicative in differentiating between IDDM and NIDDM. Obvious, that this can lead to contradictory interpretations, particularly when trying to establish a diagnose in felines, as their forms of diabetes can start out with NIDDM and progress into IDDM, and what makes it, even more, challenging, felines tend to alternate between insulin-dependence and non-dependence, due to the pathogenic dynamics between progressive dysfunction of the pancreatic parenchyma and peripheral insulin resistance (Ettinger \& Feldman 2005).

Of course, early recognition of the extent of functional $\beta$-cells are imperative for choosing the right course of action, and failure to do so, correctly and quickly, might lead to total loss.

Looking into the future, recent studies in human medicine, as well as in a small number of studies in veterinary medicine have identified C-peptide as a promising marker to measure reliably $\beta-$ -cell secretory changes, serving as an indicator for overall pancreatic functioning, permitting a more accurate differential diagnosis, and when detected early enough, might provide a good chance to avoid the progression of a diabetes disease (Gostelow 2013).

The biggest challenge, however, is the necessity to develop a "gold standard assay" of C-peptide analysis for a large variety of species and their specificities. 
One such attempt was conducted in an early 1996 study, were C-peptide plasma concentration was used to differentiate the pancreatic response during a variety of glucagon stimuli in healthy dogs, diabetic dogs, insulin treated and untreated. The result clearly stated, that the plasma C-peptide concentration measured during glucagon stimuli, permitted to differentiate between healthy dogs, dogs with diabetes mellitus, and dogs with increased $\beta$-cells response to the glucagon challenge, as it would occur with insulin resistance. The C-peptide concentrations during glucagon challenge were heterogenic in diabetic dogs, offering to differentiate between dogs with IDDM and NIDDM or, more precisely put, the severity of $\beta$-cell loss in dogs with type-I diabetes (Besch et al. 1985, Montgomery et al. 1996).

Tóth et al. (2010) employed human double antibody radioimmunoassay (RIA) for the detection of C-peptide in equine serum with the objective to read C-peptide concentrations, and to be able to analyze pancreatic function based on different stimuli. The study result was considered successful to demonstrate that C-peptide was detectable and quantifiable in equine serum.

A further study, in 2006, researcher successfully cloned and expressed the feline pro-insulin, confirming to have created a diagnostic standard for a feline-specific pro-insulin assay, which would serve as a marker to identify dysfunctional $\beta$-cells in felines (Greco 2016).

C-Peptide as a diagnostic tool to measure energy balance in wildlife. When dealing with wildlife species, minimizing stress is one of the most important responsibilities to ensure a maximum of the animal's well-being. A concept that minimizes such stress is non-invasive monitoring, where novel methods are being developed constantly and validated for different species, as introduced during the Berlin ISWE 2015 proceedings, for example: fecal, urinary, salivary, skin swipe, hair, fish scales, and baleen samples, even from whale blow (Girard-Buttoz et al. 2011, ISWE 2015).

Maintaining a positive energy balance is key to survival and reproduction. Because animals rarely live under stable, unchanging conditions, a number of factors may cause energy balance to vary in the short and/or long-term (Grueter et al. 2014). Furthermore, variability in food availability may be caused by seasonal variation or small scale patterns of habitat structure, which may, in turn, lead to fluctuations in energy intake and/or energy expenditure. Energy balance also can vary according to reproductive condition, environmental conditions, the level of infection and socioecological parameters such as dominance rank and group size (Grueter et al. 2014). A novel concept that allows monitoring an individual's nutritional status, is by measuring urinary C-peptide (UCP), (Girard-Buttoz et al. 2011).

The concept is based on the premise that food restriction would result in a decrease of Urinary C-peptide levels and again increased, once food intake continues. All related studies showed a correlation between an increased feed intake, and consequently, an increase in body mass, with a significant increase in urinary C-peptide levels. Higher UCP levels can be observed in males with higher ranking because high-ranking males have priority access to food over low ranking males, or they might occupy qualitatively better feeding spots (Surbeck et al. 2015)

Research confirmed that UCP levels are an accurate indicator for an individual's energy balance. More importantly, a reliable and cost efficient method under field conditions. All UCP reviewed studies showed research conducted on primate species, namely chimpanzees, orangutans, and macaques, in situ and in captivity (Deschner et al. 2008, Emery Thompson \& Knott 2008, Emery Thompson et al. 2009, Girard-Buttoz et al. 2011).

C-Peptide use in therapeutics. It is hypothesized, that C-peptide replacement, in conjunction with insulin therapy, might be beneficial in the treatment of microvascular complications due to C-peptide deficiencies (Wahren et al. 2007).

Studies have shown results in increased blood flow in several tissues when administered in DM Type I patients (Johansson et al. 1992).

For example, Ghorbani cited a number of studies that showed enhanced blood flow in kidneys, at the nervous system, for skeletal muscles, the myocardium, and the skin. He continues that, mediated by nitric oxide stimulation, released from endothelial cells, C-peptide executes vasodilator effects (Ghorbani \& Shafiee-Nick 2015).

Also, C-peptide replacement doses reduce glomerular hyperfiltration, diminishes urinary albumin excretion and retards or reverses renal structural abnormalities in type 1 diabetes (Wahren et al. 2007).

According to Wahren et. al. (2007), also confirmed by other studies, C-peptide replacement therapy stimulates nerve $\mathrm{Na}+\mathrm{K}+-$ ATPase activity, increases endoneurial blood flow and stimulates neurotrophic factors, resulting in improved Nerve Conduct Velocity (NCV) and prevention or reversal of nerve structural changes.

Nordquist et al. 2010, showed that diabetes provokes a reduction of $\mathrm{Na}+/ \mathrm{K}+-\mathrm{ATPa} e \mathrm{\alpha} 1$-subunit expression and their abundance in the kidney tubule, which is normally rich on such enzyme expressions (and considered the driving force behind the tubular $\mathrm{Na}+$ reabsorption). Nordquist et al. 2010, demonstrated in rats, that by chronic administration of $\mathrm{C}$ peptide in diabetic kidneys such decrease could be prevented, implying its important role in the long term regulation of $\mathrm{Na}+\mathrm{K}+$-ATPase function.

Finalizing, $\mathrm{C}$ peptide replacement therapies have been substantiated, in a number of relevant studies, as beneficial for type 1 diabetes patients (including animals), when considering treatment of early stage functional and structural abnormalities, like impaired wound healing, inflammatory processes, nephropathy, ameliorate diabetic vasculopathy, retinopathy, neuropathy, and inflammation (Johansson et al. 1992, Wahren et al. 2007, Bhatt et al. 2014).

\section{RESULTS}

In this literature review, numerous articles on C-peptide studies were identified, reporting positive results from their empirical research, validating $C$ peptide applications as an important tool in human medicine, as well as veterinary medicine. No negative statements (side effects, or serious concerns) on the use of any C-peptide application in veterinary medicine were identified. The number of publications on studies with wildlife is basically inexistent. The primate species studied, although recognized as wildlife, functioned more as laboratory animals, with the exception of a work down on wild orangutans.

\section{DISCUSSION}

The number of species researched (besides humans) is still quite limited mainly to domesticated canines, felines, equines, whereas for wildlife, only some work with primates were described. Considering that C-peptide applications are relatively new to veterinary medicine, the low numbers on related published papers are easily understood. Nonetheless, the present study suggests strongly a great potential for application of C-peptide. Whether as a biomarker for pancreatic performance in for dogs, cats, and horses, as a non invasive method to monitor nutritional status in primates, or to investigate its potential therapeutic benefits 
for diabetes related illnesses and C-Peptide deficiency. However, veterinary medicine is still at the very beginning of the application of C-peptides in clinical settings, and much more research on species-specificity needs to be done, validating assays, as well as on C peptide treatments, short,and long-term, and broadening the number of species.

This review allowed for a brief insight into the use of Cpeptide as a diagnostic tool for pancreatic performance, its active function in other biological processes, as well as its potential role in therapeutic applications, mainly in human medicine, but to a growing, and rather promising future in Veterinary Medicine.

Conflict of interest statement.- The authors have no competing interests.

\section{REFERENCES}

Abdul-Ghani M.A. \& DeFronzo R.A. 2010. Pathogenesis of insulin resistance in skeletal muscle. J. Biomed. Biotechnol. 476279.

Bachem 2015. Peptides in veterinary medicine. [WWW Document]. Arquive 2009923. Global Marketing, Bachem Group. URL <http://www.bachem.com/fileadmin/user_upload/pdf/Monographs/Veterinary_Peptides.pdf> Accessed on May 21, 2016.

Besch W., Woltanski K.P., Fischer U., Kohnert K.D. \& Ziegler M. 1985. Measurement of Plasma Canine C-Peptide by Radioimmunoassay. Exp. Clin. Endocrinol. Diabetes 86(5):146-150.

Bhatt M.P., Lim Y.C. \& Ha K.S. 2014. C-peptide replacement therapy as an emerging strategy for preventing diabetic vasculopathy. Cardiovasc. Res. 104:234-244.

Deschner T., Kratzsch J. \& Hohmann G. 2008. Urinary C-peptide as a method for monitoring body mass changes in captive bonobos (Pan paniscus). Horm. Behav. 54:620-626.

Emery Thompson M. \& Knott C.D. 2008. Urinary C-peptide of insulin as a non-invasive marker of energy balance in wild orangutans. Horm. Behav. 53:526-535.

Emery Thompson M., Muller M.N., Wrangham R.W., Lwanga J.S. \& Potts K.B. 2009. Urinary C-peptide tracks seasonal and individual variation in energy balance in wild chimpanzees. Horm. Behav. 55:299-305.

Ettinger S.J. \& Feldman E.C. 2005. Diabetes Mellitus, p.1563-1591. In: Ibid. (Eds), Textbook of Veterinary Internal Medicine. 6th ed. Elsevier Saunders, St Louis, Missouri, USA.

Ghorbani A. \& Shafiee-Nick R. 2015. Pathological consequences of C-peptide deficiency in insulin-dependent diabetes mellitus. World J. Diabetes 6:145-150.

Girard-Buttoz C., Higham J.P., Heistermann M., Wedegärtner S., Maestripieri D. \& Engelhardt A. 2011. Urinary C-peptide measurement as a marker of nutritional status in macaques. PLoS ONE 6:e18042.
Gostelow R. 2013. Achieving diabetic remission in cats [WWW Document]. Vet. Times URL <http://www.vettimes.co.uk/article/achieving-diabetic-remission-in-cats> Accessed on Jan. 19.16.

Greco D.S. 2016. Beyond Blood Sugar: early diabetes detection in cats. Clinician's Brief. URL <http://www.cliniciansbrief.com/column/diabetes/beyond-blood-sugar-early-diabetes-detection-cats> Accessed on Jan. 16, 2016.

Grueter C.C., Deschner T., Behringer V., Fawcett K. \& Robbins M.M. 2014. Socioecological correlates of energy balance using urinary C-peptide measurements in wild female mountain gorillas. Physiol. Behav. 127:13-19.

ISWE 2015. The 5th Meeting of the International Society of Wildlife Endocrinology (ISWE)', in Proceedings of the 5th ISWE Conference, Berlin, Germany <http://www.izw-berlin.de/iswe-conference-854. html?file=tl_files/downloads/ISWE2015/Proceedings\%20ISWE2015. pdf> Accessed on Jan. 16, 2016.

Johansson B.L., Linde B. \& Wahren J. 1992. Effects of C-peptide on blood flow, capillary diffusion capacity and glucose utilization in the exercising forearm of type 1 (insulin-dependent) diabetic patients. Diabetologia 35:1151-1158.

Kumar P., Kumari R.R., Kumar M., Kumar S. \& Chakrabarti A. 2014. Current practices and research updates on diabetes mellitus in canine. Vet. World 7:952-959.

McGavin M.D. \& Zachary J. 2007. Pathologic Basis of Veterinary Disease, 4th ed. Mosby/Elsevier, St Louis, Missouri, USA.

Montgomery T.M., Nelson R.W., Feldman E.C., Robertson K. \& Polonsky K.S. 1996. Basal and glucagon-stimulated plasma c-peptide concentrations in healthy dogs, dogs with diabetes mellitus, and dogs with hyperadrenocorticism. J. Vet. Intern. Med. 10:116-122.

Nordquist L., Shimada K., Ishii T., Furuya D.T., Kamikawa A. \& Kimura K. 2010. Proinsulin C-peptide prevents type- 1 diabetes-induced decrease of renal Na+-K+-ATPase $\alpha 1$-subunit in rats. Diabetes Metab. Res. Rev. 26:193-199.

O’Brien T.D. 2002. Pathogenesis of feline diabetes mellitus. Mol. Cell. Endocrinol. 197:213-219.

Sanlioglu A.D., Altunbas H.A., Balci M.K., Griffith T.S. \& Sanlioglu S. 2013. Clinical utility of insulin and insulin analogs. Islets 5:67-78.

Støy J. 2014. Mutations in the insulin gene. Diapedia 4105254815 rev. no. 6. <http://.www http://www.diapedia.org/4105254815/rev/6> Accessed on Febr. 16, 2016.

Surbeck M., Deschner T., Behringer V. \& Hohmann G. 2015. Urinary c-peptide levels in male bonobos (Pan paniscus) are related to party size and rank but not to mate competition. Horm. Behav. 71:22-30.

Tóth F., Frank N., Martin-Jiménez T., Elliott S.B., Geor R.J. \& Boston R.C. 2010. Measurement of c-peptide concentrations and responses to somatostatin, glucose infusion, and insulin resistance in horses. Equine Vet. J. 42:149-155.

Wahren J., Ekberg K. \& Jörnvall H. 2007. C-peptide is a bioactive peptide. Diabetologia 50:503-509. 